\title{
“WATER DIURESIS" PRODUCED DURING RECUMBENCY BY THE INTRAVENOUS INFUSION OF ISOTONIC SALINE SOLUTION ${ }^{1}$
}

\author{
By MAURICE B. STRAUSS, ROBERT K. DAVIS, JACK D. ROSENBAUM, AND \\ ELSIE C. ROSSMEISL
}

\author{
(From the Medical Service and Research Laboratory, Cushing Veterans Administration Hospital, \\ Framingham, Mass.)
}

(Submitted for publication April 7, 1951; accepted May 28, 1951)

Control of renal excretion of water in man is largely vested in the supra-optico-hypophyseal system. When the tonicity of the blood plasma and extracellular fluid rises, an increased secretion of antidiuretic hormone $(\mathrm{ADH})$ leads to the conservation of water inasmuch as urinary solutes are excreted with a minimum of water. Conversely, when tonicity falls, a diminution of $\mathrm{ADH}$ output permits the excretion of a large volume of dilute urine. In both instances homeostasis is served.

Many stimuli, in addition to hypertonicity, increase ADH production, including certain anaesthetic (1) and narcotic drugs (2), barbiturates $(3)$, smoking $(4,5)$ and nicotine $(6,7)$, acetylcholine (8), exercise (9), emotion (9), syncope (10), pain (11) and conditioned reflexes (11), as well as the direct electrical (12) or acetylcholine (13) stimulation of nerve cells and fibers connected with the pars nervosa of the pituitary gland. Removal of amounts of blood insufficient to alter blood pressure significantly may nevertheless lead to increased ADH activity (9). There is also suggestive evidence that there may at times be increased ADH activity in patients with cirrhosis of the liver $(14,15)$.

In contrast to the many factors which may lead to increased antidiuretic activity few other than destructive lesions involving the supra-optico-hypophyseal system and hypotonicity of the plasma and extracellular fluid have been reported to cause a decline in ADH activity. These are hypnotic suggestion (1), alcohol administration (16-18), and exposure to cold (19).

\footnotetext{
1 Reviewed in the Veterans Administration and published with the approval of the Chief Medical Director. The statements and conclusions published by the authors are the result of their own study and do not necessarily reflect the opinion or policy of the Veterans Administration.
}

It is the purpose of this communication to present evidence that a rather rapid isotonic expansion of extracellular fluid volume (or some factor associated with such a volume increase) leads to a water diuresis of the type which follows diminished ADH activity.

\section{METHODS}

The subjects were three essentially healthy male adults hospitalized for the investigation of minor symptoms for which no organic cause was found and which cleared rapidly. Without previous preparation 2 they came to the laboratory one to two hours after breakfast, voided, and began the timed collection of urine specimens. When it became apparent that the flow of urine was diminishing, blood was collected without stasis from an antecubital vein after the arm had been immersed in hot water for five minutes to arterialize the blood (20), following which $3,000 \mathrm{ml}$. of 0.9 per cent solution of sodium chloride in water ( $\mathrm{Sp} . \mathrm{Gr} .1 .005$ at $15^{\circ} \mathrm{C}$.) was infused intravenously at a constant rate of $25 \mathrm{ml} . / \mathrm{min}$., the entire infusion requiring two hours. A blood sample was collected from the opposite arm immediately upon the completion of the infusion, and a third at a subsequent time. Urine was voided at intervals during and after the infusion, the subject standing for this purpose.

The volume of packed red blood cells was measured in Wintrobe tubes (21) and hemoglobin photometrically (22) on blood rendered incoagulable by a mixture of ammonium and potassium oxalate. Serum was obtained by centrifugalization of blood collected under oil. Serum total proteins were determined by gradient tube (23); chloride by the method of Sendroy as modified by Van Slyke and Hiller (24); creatinine by the Hare adaptation of Borsook's method (25) ; and sodium and potassuim by means of the Perkin-Elmer or Barclay internal standard flame photometer. Urine specific gravity was determined with a Westphal balance; chloride by the VolhardHarvey method (26); sodium and potassium by the same

\footnotetext{
2 The unforunate lack of a truly basal or steady state for the study of water and electrolyte excretion in man has been previously discussed (17). Subjects who have had no fluids after retiring on the preceding night are for the most part somewhat hydropenic on awakening in the morning and hence have enhanced antidiuretic activity.
} 
method as employed for serum; and creatinine by Peter's modification of the Folin procedure (27). Urea and ammonia were determined together by the aeration method of Van Slyke and Cullen (28). The percentage change in plasma volume, $\mathrm{PV}_{2} / \mathrm{PV}_{1} \times 100$, was calculated from the hemoglobin and hematocrit by the formula :

$$
\frac{\mathrm{Hgb}_{1}}{\mathrm{Hgb}_{2}} \times \frac{1-\mathrm{Hct}_{2}}{1-\mathrm{Hct}_{1}} \times 100
$$

and also from the serum total protein by the formula:

$$
\frac{\mathrm{TP}_{1}}{\mathrm{TP}_{2}} \times 100
$$

\section{RESULTS}

Renal excretory rates for water and sodium, urinary specific gravity and solute concentrations, together with creatinine $\mathrm{U} / \mathrm{P}$ ratio and clearance, are shown in Table I. During diuresis urine specimens were usually obtained for analysis every half hour but the results were averaged for intervals of one to two hours except when changes of significance occurred between the shorter periods. Determinations made on venous blood and calculated changes in plasma volume are given in Table II.

TABLE I

The effect of the intravenous infusion of isotonic saline solution on urine flow, concentration of solutes,

\begin{tabular}{|c|c|c|c|c|c|c|c|c|c|c|c|}
\hline \multirow{2}{*}{$\begin{array}{l}\text { Subject } \\
\text { date }\end{array}$} & \multirow{2}{*}{ Position } & \multirow{2}{*}{ Time } & \multirow{2}{*}{$\begin{array}{l}\text { Urine } \\
\text { flow }\end{array}$} & \multirow{2}{*}{$\begin{array}{l}\text { Spec. grav.** } \\
\text { (at } 15^{\circ} \text { C.) }\end{array}$} & \multirow{2}{*}{$\mathrm{Na}$} & \multirow{2}{*}{$\mathrm{Cl}$} & \multirow{2}{*}{$\mathbf{K}$} & \multirow{2}{*}{$\underset{\text { ureat }}{\text { Urea }+\mathrm{NH}_{3}}$} & \multicolumn{2}{|c|}{ Creatinine } & \multirow{2}{*}{$\underset{\text { tion }}{\text { Na excre- }}$} \\
\hline & & & & & & & & & $\underset{\text { ratio }}{\mathrm{U} / \mathrm{P}}$ & Clearance & \\
\hline $\begin{array}{l}\text { E. F. } \\
1 / 12 / 51\end{array}$ & $\begin{array}{l}\text { Recumbent } \\
\text { Recumbent } \\
\text { Recumbent } \\
\text { Recumbent } \\
\text { Recumbent }\end{array}$ & $\begin{array}{c}\text { min. } \\
-60 \text { to } 0 \ddagger \\
0 \text { to } 60(1) \\
61 \text { to } 120 \\
121 \text { to } 150 \\
151 \text { to } 240\end{array}$ & $\begin{array}{c}\operatorname{ml} . / \min . \\
2.25 \\
2.08 \\
7.08 \\
9.08 \\
3.55\end{array}$ & $\begin{array}{l}08 \\
10 \\
02 \\
05 \\
08\end{array}$ & $\begin{array}{c}\text { meq./l. } \\
163 \\
164 \\
86 \\
119 \\
196\end{array}$ & $\begin{array}{c}\text { meq./l. } \\
168 \\
183 \\
88 \\
120 \\
200\end{array}$ & $\begin{array}{c}\text { meg. } / l . \\
39 \\
33 \\
5 \\
4 \\
18\end{array}$ & $\begin{array}{c}m M / l \\
156 \\
170 \\
33 \\
31 \\
82\end{array}$ & $\begin{array}{l}58 \\
67 \\
13 \\
12 \\
34\end{array}$ & $\begin{array}{c}\text { ml./min. } \\
131 \\
139 \\
92 \\
109 \\
121\end{array}$ & $\begin{array}{c}\text { micro-eq. } \\
\text { min. } \\
367 \\
341 \\
609 \\
1081 \\
696\end{array}$ \\
\hline $1 / 9 / 51$ & $\begin{array}{l}\text { Sitting } \\
\text { Sitting } \\
\text { Sitting } \\
\text { Recumbent } \\
\text { Recumbent }\end{array}$ & $\begin{array}{r}-60 \text { to } 0 \\
0 \text { to } 138(2) \\
139 \text { to } 180 \\
181 \text { to } 210 \\
211 \text { to } 240\end{array}$ & $\begin{array}{l}0.75 \\
1.70 \\
1.67 \\
3.13 \\
5.00\end{array}$ & $\begin{array}{l}20 \\
12 \\
09 \\
05 \\
05\end{array}$ & $\begin{array}{r}174 \\
187 \\
176 \\
138 \\
90\end{array}$ & $\begin{array}{l}218 \\
238 \\
242 \\
147 \\
105\end{array}$ & $\begin{array}{l}79 \\
72 \\
60 \\
28 \\
15\end{array}$ & $\begin{array}{r}470 \\
220 \\
219 \\
118 \\
73\end{array}$ & $\begin{array}{r}191 \\
82 \\
82 \\
48 \\
30\end{array}$ & $\begin{array}{l}143 \\
139 \\
137 \\
150 \\
150\end{array}$ & $\begin{array}{l}131 \\
318 \\
294 \\
432 \\
450\end{array}$ \\
\hline $\begin{array}{l}\text { S. C. } \\
2 / 6 / 51\end{array}$ & $\begin{array}{l}\text { Recumbent } \\
\text { Recumbent } \\
\text { Recumbent } \\
\text { Recumbent }\end{array}$ & $\begin{array}{r}-60 \text { to } 0 \\
0 \text { to } 120(3) \\
121 \text { to } 180 \\
181 \text { to } 270\end{array}$ & $\begin{array}{l}2.36 \\
3.39 \\
8.34 \\
4.11\end{array}$ & $\begin{array}{l}12 \\
06 \\
02 \\
09\end{array}$ & $\begin{array}{r}93 \\
82 \\
64 \\
173\end{array}$ & $\begin{array}{r}128 \\
96 \\
66 \\
183\end{array}$ & $\begin{array}{l}65 \\
33 \\
12 \\
29\end{array}$ & $\begin{array}{r}204 \\
114 \\
47 \\
103\end{array}$ & $\begin{array}{l}63 \\
40 \\
18 \\
39\end{array}$ & $\begin{array}{l}149 \\
136 \\
150 \\
160\end{array}$ & $\begin{array}{l}219 \\
278 \\
534 \\
711\end{array}$ \\
\hline $2 / 9 / 51$ & $\begin{array}{l}\text { Sitting } \\
\text { Sitting } \\
\text { Sitting } \\
\text { Recumbent } \\
\text { Recumbent }\end{array}$ & $\begin{array}{r}-60 \text { to } 0 \\
0 \text { to } 145(4) \\
146 \text { to } 225 \\
226 \text { to } 285 \\
286 \text { to } 345\end{array}$ & $\begin{array}{l}1.33 \\
1.38 \\
3.63 \\
2.30 \\
4.94\end{array}$ & $\begin{array}{l}20 \\
15 \\
12 \\
14 \\
04\end{array}$ & $\begin{array}{r}84 \\
126 \\
144 \\
160 \\
91\end{array}$ & $\begin{array}{l}175 \\
194 \\
189 \\
197 \\
101\end{array}$ & $\begin{array}{r}123 \\
92 \\
57 \\
59 \\
30\end{array}$ & $\begin{array}{r}403 \\
273 \\
157 \\
173 \\
80\end{array}$ & $\begin{array}{r}153 \\
110 \\
66 \\
73 \\
30\end{array}$ & $\begin{array}{l}203 \\
152 \\
240 \\
168 \\
148\end{array}$ & $\begin{array}{l}112 \\
174 \\
523 \\
368 \\
450\end{array}$ \\
\hline $\begin{array}{l}\text { E. B. } \\
1 / 24 / 51\end{array}$ & $\begin{array}{l}\text { Recumbent } \\
\text { Recumbent } \\
\text { Recumbent } \\
\text { Recumbent } \\
\text { Recumbent } \\
\text { Recumbent }\end{array}$ & $\begin{array}{r}-105 \text { to } 0 \\
0 \text { to } 119(5) \\
120 \text { to } 180 \\
181 \text { to } 240 \\
241 \text { to } 300 \\
301 \text { to } 330\end{array}$ & $\begin{array}{l}1.24 \\
1.65 \\
3.00 \\
4.35 \\
5.17 \\
3.67\end{array}$ & $\begin{array}{l}16 \\
14 \\
13 \\
08 \\
03 \\
06\end{array}$ & $\begin{array}{r}130 \\
176 \\
217 \\
149 \\
87 \\
127\end{array}$ & $\begin{array}{l}146 \\
202 \\
238 \\
161 \\
101 \\
130\end{array}$ & $\begin{array}{l}42 \\
58 \\
38 \\
27 \\
17 \\
23\end{array}$ & $\begin{array}{r}260 \\
164 \\
114 \\
84 \\
62 \\
85\end{array}$ & $\begin{array}{r}101 \\
67 \\
42 \\
30 \\
24 \\
33\end{array}$ & $\begin{array}{l}125 \\
111 \\
126 \\
131 \\
124 \\
121\end{array}$ & $\begin{array}{l}161 \\
290 \\
651 \\
648 \\
450 \\
466\end{array}$ \\
\hline $1 / 29 / 51$ & $\begin{array}{l}\text { Sitting } \\
\text { Sitting } \\
\text { Sitting } \\
\text { Sitting } \\
\text { Recumbent } \\
\text { Recumbent } \\
\text { Recumbent } \\
\text { Recumbent }\end{array}$ & $\begin{array}{r}-97 \text { to } 0 \\
0 \text { to } 119(6) \\
120 \text { to } 197 \\
198 \text { to } 285 \\
286 \text { to } 315 \\
316 \text { to } 347 \\
348 \text { to } 375 \\
376 \text { to } 405\end{array}$ & $\begin{array}{l}0.93 \\
1.30 \\
2.75 \\
2.75 \\
3.66 \\
6.56 \\
5.00 \\
2.67\end{array}$ & $\begin{array}{l}20 \\
19 \\
12 \\
13 \\
07 \\
03 \\
04 \\
13\end{array}$ & $\begin{array}{r}198 \\
192 \\
209 \\
174 \\
116 \\
75 \\
109 \\
189\end{array}$ & $\begin{array}{r}241 \\
256 \\
243 \\
198 \\
132 \\
77 \\
113 \\
198\end{array}$ & $\begin{array}{l}77 \\
88 \\
56 \\
53 \\
31 \\
20 \\
27 \\
41\end{array}$ & $\begin{array}{r}318 \\
209 \\
120 \\
140 \\
104 \\
35 \\
58 \\
98\end{array}$ & $\begin{array}{r}146 \\
100 \\
43 \\
42 \\
36 \\
17 \\
25 \\
40\end{array}$ & $\begin{array}{l}136 \\
130 \\
118 \\
116 \\
132 \\
112 \\
125 \\
107\end{array}$ & $\begin{array}{l}185 \\
250 \\
575 \\
479 \\
425 \\
492 \\
545 \\
505\end{array}$ \\
\hline
\end{tabular}
creatinine $U / P$ ratio, creatinine clearance, and sodium excretion rate

* The second and third digits after the decimal are shown.

† Urea and ammonia nitrogen were determined together but are recorded as if all the nitrogen was in the form of urea.

$\ddagger$ Infusion begun at, and completed at $(1)+10,+130,(2)+15,+135,(3)+10,+135,(4)+19,+135,(5)+9$, $+135,(6)+17,+130$ minutes. 
TABLE II

The effect of the intravenous infusion of isotonic saline solution on constituents of the blood and on the volume of the plasma

\begin{tabular}{|c|c|c|c|c|c|c|c|c|c|c|}
\hline \multirow{2}{*}{$\begin{array}{l}\text { Subject } \\
\text { Date } \\
\text { Position }\end{array}$} & \multirow{2}{*}{ Time } & \multirow{2}{*}{$\underset{\text { crit }}{\text { Hemato- }}$} & \multirow{2}{*}{$\underset{\text { bin }}{\text { Hemoglo- }}$} & \multirow{2}{*}{$\begin{array}{c}\text { Total } \\
\text { serum } \\
\text { protein }\end{array}$} & \multirow{2}{*}{$\underset{\text { creatinine }}{\text { Serum }}$} & \multicolumn{3}{|c|}{$\begin{array}{c}\text { Concentration in extra- } \\
\text { cellular } \mathrm{H}: 0\end{array}$} & \multicolumn{2}{|c|}{$\mathrm{PV}_{2} / \mathrm{PV}_{1} \times 100$} \\
\hline & & & & & & $\mathbf{N a}$ & $\mathrm{Cl}$ & $\mathbf{K}$ & $\begin{array}{l}\text { (from Hct. } \\
\text { and Hgb.) }\end{array}$ & $\stackrel{\text { (from }}{\text { T.P.) }}$ \\
\hline $\begin{array}{l}\text { E. F. } \\
1 / 12 / 51 \\
\text { Recumbent }\end{array}$ & $\begin{array}{r}\min . \\
10 \\
135 \\
245\end{array}$ & $\begin{array}{c}\text { vol. } \% \\
48.0 \\
43.6 \\
44.6\end{array}$ & $\begin{array}{l}\text { gm. \% } \\
15.2 \\
14.1 \\
14.4\end{array}$ & $\begin{array}{c}g m . \% \\
7.1 \\
6.1 \\
6.4\end{array}$ & \begin{tabular}{|c|}
$\mathrm{mg} . / 100 \mathrm{ml}$. \\
0.95 \\
0.85 \\
0.88
\end{tabular} & $\begin{array}{l}\text { meq./l. } \\
138.4 \\
145.2 \\
140.7\end{array}$ & $\begin{array}{l}\text { meq./l. } \\
118.0 \\
125.7 \\
124.1\end{array}$ & $\begin{array}{c}\text { meq./l. } \\
4.9 \\
4.6 \\
4.8\end{array}$ & $\begin{array}{c}\% \\
100.0 \\
116.9 \\
112.5\end{array}$ & $\begin{array}{c}\% \\
100.0 \\
116.4 \\
110.9\end{array}$ \\
\hline $\begin{array}{l}1 / 9 / 51 \\
\text { Sitting and } \\
\text { recumbent }\end{array}$ & $\begin{array}{r}15 \\
145\end{array}$ & $\begin{array}{l}47.9 \\
43.0\end{array}$ & $\begin{array}{l}15.2 \\
13.4\end{array}$ & $\begin{array}{l}7.2 \\
6.1\end{array}$ & $\begin{array}{l}0.92 \\
0.87\end{array}$ & $\begin{array}{l}144.3 \\
144.8\end{array}$ & $\begin{array}{l}118.4 \\
124.0\end{array}$ & $\begin{array}{l}5.1 \\
5.0\end{array}$ & $\begin{array}{l}100.0 \\
124.3\end{array}$ & $\begin{array}{l}100.0 \\
118.0\end{array}$ \\
\hline $\begin{array}{l}\text { S. C. } \\
2 / 6 / 51 \\
\text { Recumbent }\end{array}$ & $\begin{array}{r}10 \\
133 \\
223\end{array}$ & $\begin{array}{l}47.0 \\
43.0 \\
41.0\end{array}$ & $\begin{array}{l}15.2 \\
14.0 \\
13.2\end{array}$ & $\begin{array}{l}6.5 \\
5.7 \\
5.7\end{array}$ & $\begin{array}{l}1.06 \\
0.94 \\
1.06\end{array}$ & $\begin{array}{l}141.5 \\
145.0 \\
143.7\end{array}$ & $\begin{array}{l}118.8 \\
125.9 \\
123.2\end{array}$ & $\begin{array}{l}4.4 \\
4.4 \\
4.3\end{array}$ & $\begin{array}{l}100.0 \\
116.8 \\
128.2\end{array}$ & $\begin{array}{l}100.0 \\
114.0 \\
114.0\end{array}$ \\
\hline $\begin{array}{l}2 / 9 / 51 \\
\text { Sitting and } \\
\text { recumbent }\end{array}$ & $\begin{array}{r}17 \\
145 \\
345\end{array}$ & $\begin{array}{l}49.1 \\
42.0 \\
44.0\end{array}$ & $\begin{array}{l}15.8 \\
13.7 \\
14.7\end{array}$ & $\begin{array}{l}7.2 \\
5.8 \\
6.0\end{array}$ & $\begin{array}{l}0.91 \\
0.87 \\
0.94\end{array}$ & $\begin{array}{l}138.9 \\
141.7 \\
138.5\end{array}$ & $\begin{array}{l}116.3 \\
121.4 \\
121.3\end{array}$ & $\begin{array}{l}4.7 \\
4.9 \\
4.1\end{array}$ & $\begin{array}{l}100.0 \\
131.4 \\
118.3\end{array}$ & $\begin{array}{l}100.0 \\
124.1 \\
120.0\end{array}$ \\
\hline $\begin{array}{l}\text { E. B. } \\
1 / 24 / 51 \\
\text { Recumbent }\end{array}$ & $\begin{array}{r}9 \\
143 \\
338\end{array}$ & $\begin{array}{l}41.7 \\
37.3 \\
38.2\end{array}$ & $\begin{array}{l}13.1 \\
11.6 \\
11.9\end{array}$ & $\begin{array}{l}7.0 \\
6.1 \\
6.3\end{array}$ & $\begin{array}{l}1.28 \\
1.13 \\
1.10\end{array}$ & $\begin{array}{l}147.9 \\
145.4 \\
143.8\end{array}$ & $\begin{array}{l}118.9 \\
124.6 \\
125.2\end{array}$ & $\begin{array}{l}4.8 \\
4.4 \\
4.7\end{array}$ & $\begin{array}{l}100.0 \\
121.5 \\
116.7\end{array}$ & $\begin{array}{l}100.0 \\
114.8 \\
111.1\end{array}$ \\
\hline $\begin{array}{l}1 / 29 / 51 \\
\text { Sitting and } \\
\text { recumbent }\end{array}$ & $\begin{array}{r}15 \\
135 \\
350\end{array}$ & $\begin{array}{l}42.3 \\
36.9 \\
39.0\end{array}$ & $\begin{array}{l}12.8 \\
11.3 \\
12.0\end{array}$ & $\begin{array}{l}7.0 \\
5.9 \\
6.3\end{array}$ & $\begin{array}{l}1.26 \\
1.12 \\
1.08\end{array}$ & $\begin{array}{l}144.4 \\
146.1 \\
143.7\end{array}$ & $\begin{array}{l}120.1 \\
124.8 \\
124.0\end{array}$ & $\begin{array}{l}5.4 \\
4.6 \\
5.3\end{array}$ & $\begin{array}{l}100.0 \\
123.7 \\
112.8\end{array}$ & $\begin{array}{l}100.0 \\
118.6 \\
111.1\end{array}$ \\
\hline
\end{tabular}

Infusion was begun immediately after the first blood sample was obtained and concluded just prior to withdrawing the second sample.

E. F. weighed 82 kg., S. C., 91 kg., E. B., 75 kg.

The rate of urine flow together with the value approximating the total electrolyte concentration, $2(\mathrm{Na}+\mathrm{K})$, have been charted in Figures 1-3. In each experiment, during or following the infusion the rate of urine formation rose sharply and the concentration of electrolyte fell below that of extracellular water as well as below that of the infusion fluid. Specific gravity of the urine as well as the concentration of urea plus ammonia fell concomitantly with the decline in electrolyte concentration. The rate of sodium and chloride excretion rose in each instance during the saline infusion and

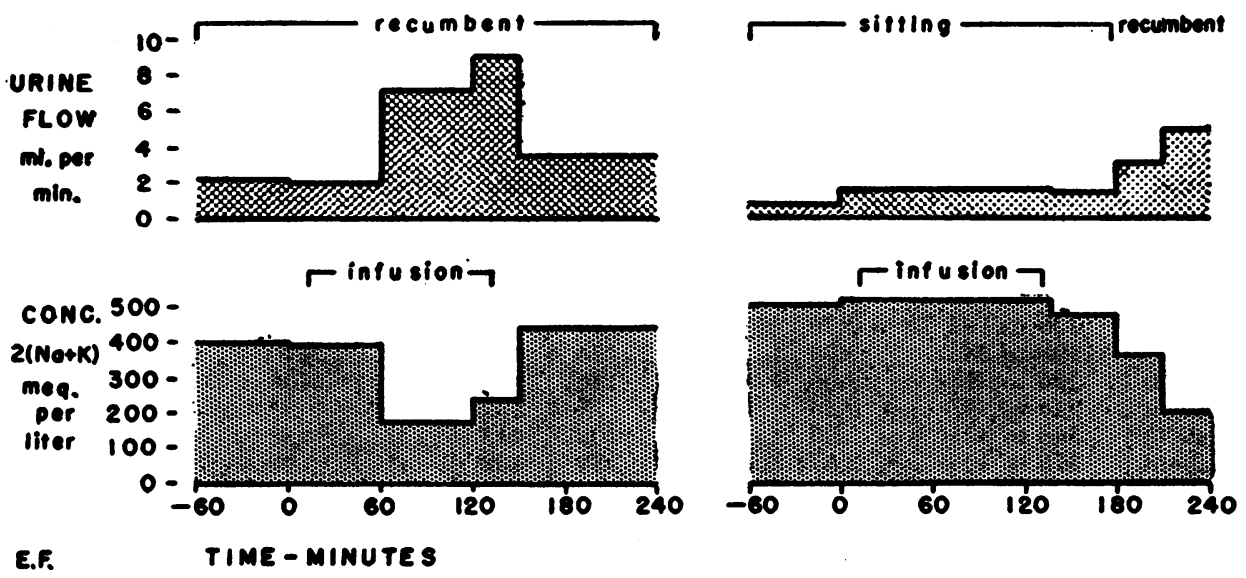

Fig. 1. Electrolyte Concentration and Flow of Urine in Relation to the Intravenous Infusion of Isotonic Saline and to Change in Posture-Patient E. F. 

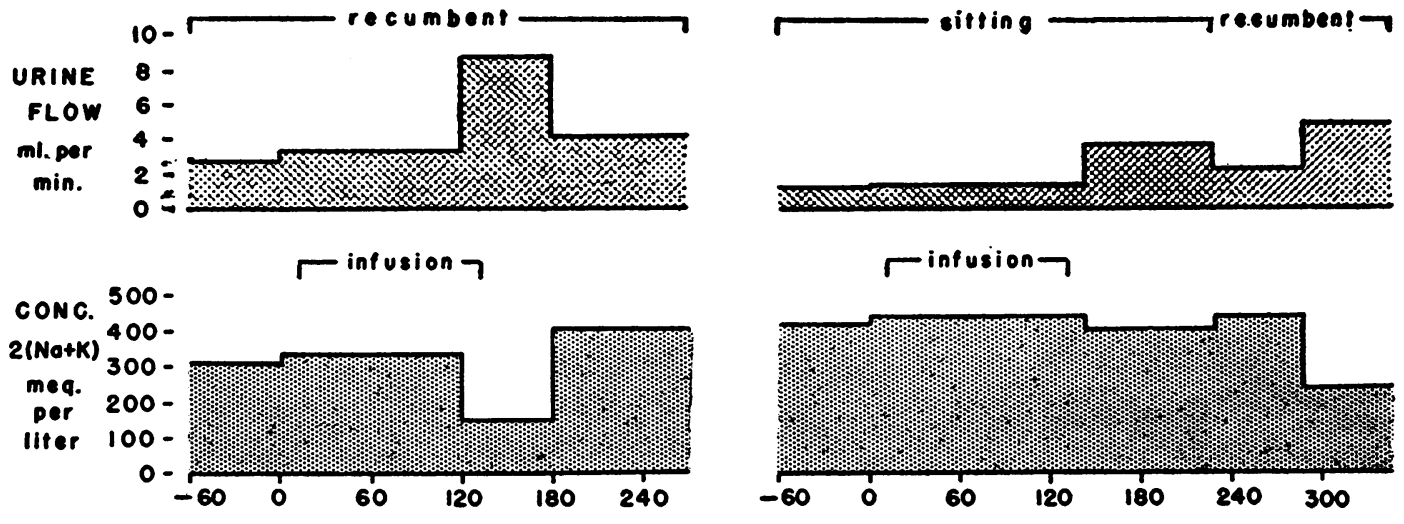

S.C. TIME - MINUTES

Legend as in Figure 1.

Fig. 2. Patient S. C.

continued well above the fore-period level throughout the entire post-infusion period. At the time that the urine was most hypotonic, the excretion rate of sodium and chloride averaged 2.6 times as great as in the fore-period.

It will be noted that in each instance with the subject sitting the urine flow was less and the electrolyte concentration greater during the fore-period than during recumbency. The creatinine $\mathrm{U} / \mathrm{P}$ ratios were correspondingly higher with the subjects sitting. In the case of E. F., whose creatinine $\mathrm{U} / \mathrm{P}$ ratio in the fore-period was 58 while recumbent, the most hypotonic urine was secreted during the second hour of the infusion and in S. C., tonicity was lowest during the first hour after the infusion. In the third subject, E. B., whose creatinine $\mathrm{U} / \mathrm{P}$ ratio was considerably higher during the fore-period, and who was disturbed by the intravenous infusion (becoming pale and faint when the needle was inserted) the most hypotonic urine was not obtained until two hours after the completion of the infusion. In contrast, with the same subjects sitting, hypotonic urine was not elaborated during even longer periods of time, but was secreted one-half to one hour after recumbency was assumed.

The variation in endogenous creatinine clearance in some experiments may be explained in part by incomplete bladder emptying at low rates of urine flow. Although a rather consistent trend to lower clearance values may be noted in the periods during or just after the intravenous infusion, the significance of this is uncertain. Since, in these observations, concentration of urinary solutes was the variable under study and not their rate of output, and since the change under consideration was a fall of tonicity of the urine, collection and timing errors could only serve to delay the recognition of
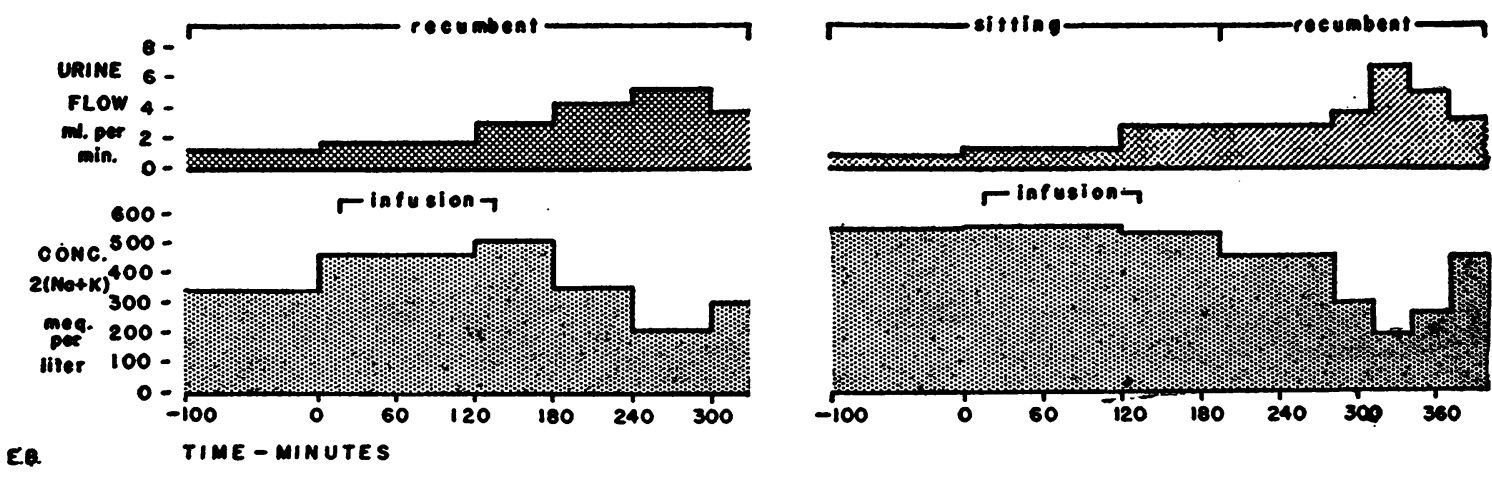

Legend as in Figure 1.

Fig. 3. Patient E. B. 
such a fall in tonicity or decrease its apparent magnitude. Although more accuracy could have been achieved by means of an indwelling catheter, the presence of such a foreign body in the urethra for a period of many hours would not be conducive to minimum emotional stimulation of the supraoptico-hypophyseal system.

\section{DISCUSSION}

In each of the six experiments described above, during or following the infusion of 3 liters of an 0.9 per cent solution of $\mathrm{NaCl}$, the urine volume rose sharply and the concentration of both $\mathrm{Na}$ and $\mathrm{Cl}$ fell to below their respective concentrations in the extracellular water as well as below their concentrations in the infusion solution, while the urinary specific gravity measured at $15^{\circ} \mathrm{C}$. fell to or below 1.005 in the sitting and 1.003 in the recumbency studies. The concentration of urea plus ammonia concomitantly fell to less than one-fourth of the pre-infusion concentration in each instance. This excretion of water in excess of solutes is characteristic of the diuresis which follows the ingestion of water, of alcohol (17), of exposure to cold (19), and damage to the supra-optico-hypophyseal system (1). It may be inhibited in these instances by the administration of pitressin. In the experiments reported above the duration of the diuresis was limited, presumably because of stimulation of the supra-optico-hypophyseal mechanism by the increasing tonicity of the plasma and extracellular fluid which must of necessity have occurred since during the diuresis water was excreted in excess of solutes.

Murphy has observed that subjects receiving $20-30 \mathrm{ml} . / \mathrm{kg}$. of 0.85 per cent $\mathrm{NaCl}$ intravenously in 25-40 minutes have an initial water diuresis which he suggested was "related to dilution of circulating pitressin and related renal tubular effects" (29). In view of the fact that such dilution in our experiments should have been maximal at the conclusion of the infusion but diuresis did not occur in the sitting subjects until they assumed the recumbent position, sometimes several hours later, this hypothesis receives no support.

Welt and Orloff (30) have found that the intravenous administration of 4-6 per cent albumin in normal salt solution leads, in semi-recumbent subjects, to a water diuresis of as great or greater magnitude than that encountered in the studies reported here. Thus their observations indicate that it is not the dilution of the plasma proteins which is involved in the response. It is of interest that when, as a control for the albumin in saline experiments, they administered $2,500 \mathrm{ml}$. of saline alone intravenously there was no clear-cut water diuresis, although during the first hour of the infusion the urinary concentration of sodium chloride fell to 100 meq./1., and rose only to $145 \mathrm{meq} . / 1$. during the second hour. The difference between these findings and those reported here may be due to the fact that their subject received no fluids for 12-14 hours before the infusion and that he was semi-recumbent on a couch rather than flat on a bed.

Since the water diuresis produced by 4 per cent albumin in saline could be inhibited by adding 200 milli-units of posterior pituitary hormone to the infusion, Welt and Orloff suggested that the diuresis was produced by suppression of posterior pituitary activity.

Our observations, demonstrating that the isotonic expansion of extracellular fluid volume (both intra- and extravascular) was ineffective under the conditions of study in producing a water diuresis in the sitting subject, but did so during recumbency, suggest that the receptors for expanded volume (or an associated factor) may have their locus in the cephalad portion of the body. Since the supra-optico-hypophyseal system is believed to be largely involved in the control of water excretion and since it is so located, it may be suggested that the receptor cells, known to respond to changes in osmotic pressure, may also respond to hydrostatic pressure.

The failure of Lewis and associates (31) to secure consistent changes in the rate of urine flow by compression of the neck with an inflated blood pressure cuff, a maneuver which presumably increased the intracranial pressure, may well have been due to the antidiuretic effect of the considerable discomfort produced by the procedure.

The fact that an isotonic expansion of extracellular volume of some magnitude did not initiate a water diuresis in the sitting position is of interest in connection with the observation recorded for the fore-period here which has been repeatedly made in other studies (32-37) that the normally hy- 
drated subject has an increased water diuresis upon lying down, with a decrease in urinary electrolyte concentration. This water diuresis, presumably due to decreased $\mathrm{ADH}$ action, differs from the comparable increase in urine volume encountered in the water-loaded subject, in whom $\mathrm{ADH}$ activity is presumably already minimal and whose excretion and concentration of electrolyte both rise upon assuming the recumbent position (37). The enhanced excretion of both water and electrolyte which occurs in edematous states associated with both heart and liver disease when the patient assumes a more recumbent position (38) may well be due in part to the redistribution of the already isotonically expanded extracellular volume.

\section{CONCLUSIONS}

1. Antidiuretic activity, ordinarily diminished by hypotonicity of the extracellular fluid, may also be diminished in the recumbent subject by isotonic expansion of the extracellular fluid volume.

2. The fact that an equal expansion of extracellular volume in the sitting subject does not significantly diminish antidiuretic activity, although there is an equal or greater expansion of both plasma and extracellular volume, suggests that the distribution as well as the magnitude of the expanded extracellular volume is of importance.

\section{ACKNOWLEDGMENTS}

The technical assistance of Mrs. Eleanor Harkins and Miss Miriam Halpin is gratefully acknowledged.

\section{REFERENCES}

1. Pickford, M., Control of the secretion of the antidiuretic hormone from the pars nervosa of the pituitary gland. Physiol. Rev., 1945, 25, 573.

2. de Bodo, R. C., The antidiuretic action of morphine and its mechanism. J. Pharmacol. \& Exper. Therap., 1944, 82, 74.

3. de Bodo, R. C., and Prescott, K. F., The antidiuretic action of barbiturates (phenobarbital, amytal, pentobarbital) and the mechanism involved in this action. J. Pharmacol. \& Exper. Therap., 1945, 85, 222.

4. Walker, J. M., The effect of smoking on water diuresis in man. Quart. J. Med., 1949, 18, 51.

5. Sinclair-Smith, B. C., Sisson, J., Kattus, A. A., Genecin, A., Monge, C., McKeever, W., and Newman, E. V., The effects of posterior pituitary extract and smoking on water, sodium and chloride excretion in normal subjects and in patients with congestive cardiac failure. Bull. Johns Hopkins Hosp., 1950, 87, 221.

6. Burn, J. H., Truelove, L. H., and Burn, I., The antidiuretic action of nicotine and of smoking. Brit. M. J., 1945, 1, 403.

7. Eggleton, M. G., The effect of nicotine on the diuresis induced by ethyl alcohol. J. Physiol., 1949, 108, 482.

8. Pickford, M., The inhibitory effect of acetylcholine on water diuresis in the dog, and its pituitary transmission. J. Physiol., 1939, 95, 226.

9. Rydin, H., and Verney, E. B., The inhibition of water diuresis by emotional stress and by muscular exercise. Quart. J. Exper. Physiol., 1938, 27, 343.

10. Brun, C., Knudsen, E. O. E., and Raaschou, F., Kidney function and circulatory collapse. Post-syncopal oliguria. J. Clin. Invest., 1946, 25, 568.

11. Theobald, G. W., The repetition of certain experiments on which Molitor and Pick base their watercentre hypothesis, and the effect of afferent nerve stimuli on water diuresis. J. Physiol., 1934, 81, 243.

12. Haterius, H. O., Evidence of pituitary involvement in the experimental control of water diuresis. Am. J. Physiol., 1940, 128, 506.

13. Pickford, M., The action of acetylcholine in the supraoptic nucleus of the chloralosed dog. J. Physiol., 1947, 106, 264.

14. Ralli, E. P., Robson, J. S., Clarke, D., and Hoagland, C. L., Factors influencing ascites in patients with cirrhosis of the liver. J. Clin. Invest., 1945, 24, 316.

15. Nelson, W. P., III., Rosenbaum, J. D., and Strauss, M. B., Hyponatremia in portal cirrhosis with ascites. Am. J. Med., 1951, 10, 231.

16. Eggleton, M. G., The diuretic action of alcohol in man. J. Physiol., 1942, 101, 172.

17. Strauss, M. B., Rosenbaum, J. D., and Nelson, W. P., III, The effect of alcohol on the renal excretion of water and electrolyte. J. Clin. Invest., 1950, 29, 1053.

18. van Dyke, H. B., and Ames, R. G., Alcohol diuresis. Acta Endocrinol., in press.

19. Bader, R. A., Eliot, J. W., and Bass, D. E., Renal and hormonal mechanisms of cold diuresis. Federation Proc., 1949, 8, 7.

20. Meakins, J. C., and Davies, H. W., Observations on the gases in human arterial and venous blood. $\mathrm{J}$. Path. \& Bact., 1920, 23, 451.

21. Wintrobe, M. M., The size and hemoglobin content of the erythrocyte; methods of determination and clinical application. J. Lab. \& Clin. Med., 1932, 17, 899.

22. Sanford, A. H., Sheard, C., and Osterberg, A. E., The photelometer and its use in the clinical laboratory. Am. J. Clin. Path., 1933, 3, 405.

23. Lowry, O. H., and Hunter, T. H., The determination of serum protein concentration with a gradient tube. J. Biol. Chem., 1945, 159, 465. 
24. Van Slyke, D. D., and Hiller, A., Application of Sendroy's iodometric chloride titration to protein-containing fluids. J. Biol. Chem., 1947, 167, 107.

25. Hare, R. S., Endogenous creatinine in serum and urine. Proc. Soc. Exper. Biol. \& Med., 1950, 74, 148.

26. Peters, J. P., and Van Slyke, D. D., Quantitative Clinical Chemistry. Volume II. Methods. Williams \& Wilkins, Baltimore, 1932, pp. 832-835.

27. Peters, J. H., The determination of creatinine and creatine in blood and urine with the photoelectric colorimeter. J. Biol. Chem., 1942, 146, 179.

28. Van Slyke, D. D., and Cullen, G. E., The determination of urea by the urease method. J. Biol. Chem., 1916, 24, 117.

29. Murphy, J. F., Studies on the mechanisms of saline diuresis. J. Clin. Invest., 1950, 29, 836.

30. Welt, L. G., and Orloff, J., The effects of an increase in plasma volume on the metabolism and excretion of water and electrolytes by normal subjects. J. Clin. Invest., 1951, 30, 751.

31. Lewis, J. M., Jr., Buie, R. M., Sevier, S. M., and Harrison, T. R., The effect of posture and of congestion of the head on sodium excretion in normal subjects. Circulation, 1950, 2, 822.
32. Erlanger, J., and Hooker, D. R., An experimental study of the blood pressure and pulse pressure in man. Johns Hopkins Hosp. Rep., 1904, 12, 145.

33. Adolph, E. F., The regulation of the water content of the human organism. J. Physiol., 1921, 55, 114.

34. White, H. L., Rosen, I. T., Fischer, S. S., and Wood, G. H., The influence of posture on renal activity. Am. J. Physiol., 1926, 78, 185.

35. Ni, T. G., and Rehberg, P. B., On the influence of posture on kidney function. J. Physiol., 1931, 71, 331.

36. Brun, C., Knudsen, E. O. E., and Raaschou, F., Influence of posture on kidney function. I. The fall in the diuresis in the erect posture. Acta med. Scandinav., 1945, 122, 315.

37. Rosenbaum, J. D., Nelson, W. P., III., and Strauss, M. B., Unpublished observations.

38. Borst, J. G. G., and de Vries, L. A., The three types of "natural" diuresis. Lancet, 1950, $2,1$.

Since this manuscript was submitted for publication, G. Blomhert has published a doctoral thesis (Over de zogenaamde waterdiurese, Scheltema \& Holkema, Amsterdam, 1951) in which he describes the production of a "waterdiuresis" in recumbent subjects receiving isotonic saline either by mouth or by vein. 